\title{
Further Dibromotyrosine-Derived Metabolites from the Marine Sponge Aplysina caissara
}

\author{
Tatiana O. de Lira, ${ }^{a}$ Roberto G. S. Berlinck, ${ }^{*, a}$ Gislene G. F. Nascimento ${ }^{b}$ and Eduardo Hajdu ${ }^{c} \quad \frac{\mathbf{\Omega}}{\mathbf{0}}$ \\ ${ }^{a}$ Instituto de Química de São Carlos, Universidade de São Paulo, CP 780, 13560-970 São Carlos-SP, Brazil \\ ${ }^{b}$ Faculdade de Ciências da Saúde, Universidade Metodista de Piracicaba, Rodovia do Açúcar, km 156, \\ 13400-901 Piracicaba-SP, Brazil \\ ${ }^{c}$ Museu Nacional, Universidade Federal do Rio de Janeiro, Quinta da Boa Vista, s/n, 20940-040 \\ Rio de Janeiro-RJ, Brazil
}

\begin{abstract}
A re-investigação química do extrato bruto da esponja Aplysina caissara levou ao isolamento de cinco novos derivados da dibromotirosina, denominados agelocaissarinas A1, A2, B1, B2 e caissarina $\mathrm{C}$, além dos já conhecidos fistularina-3 e 11-hidroxiaerotionina. Os compostos isolados tiveram suas estruturas determinadas pela análise de seus espectros de RMN mono- e bidimensionais, espectro de massas de alta resolução, infravermelho e ultravioleta. A configuração relativa das agelocaissarinas pôde ser estabelecida por análise dos espectros de $\mathrm{RMN}-{ }^{1} \mathrm{H}$ e modelagem molecular, enquanto que a configuração absoluta do sistema espiroxazolidínico da fistularina-3, da caissarina $\mathrm{C}$ e da 11-hidroxiaerotionina pôde ser estabelecida pela análise de seus espectros de dicroísmo circular. A fistularina-3 e a 11hidroxiaerotionina apresentaram atividade antibiótica moderada contra várias linhagens de bactérias patogênicas.
\end{abstract}

The re-investigation of the crude extract obtained from the sponge Aplysina caissara led to the isolation of five new dibromotyrosine derivatives, named agelocaissarines A1, A2, B1, B2 and caissarine $\mathrm{C}$, along with the already known fistularin-3 and 11-hydroxyaerothionin. All compounds were identified by analysis of mono- and bidimensional NMR spectra, high resolution mass spectra, infrared and ultraviolet spectra. The relative stereochemistry of agelocaissarines could be established by analysis of ${ }^{1} \mathrm{H}$ NMR spectra and molecular modeling, while the absolute configuration of the spiroxazolidine moieties of fistularin-3, caissarine $\mathrm{C}$ and 11 hydroxyaerothionin was established by analysis of ${ }^{1} \mathrm{H}$ NMR and circular dichroism spectra. Fistularin-3 and 11-hydroxyaerothionin displayed moderate antibiotic activity against several pathogenic bacteria.

Keywords: sponge, Aplysina caissara, dibromotyrosine, absolute configuration

\section{Introduction}

Marine sponges constitute a remarkable source of novel, potently bioactive secondary metabolites. ${ }^{1,2}$ In particular, sponges of the order Verongida have been the source of a variety of biologically active dibromotyrosine-derived modified peptides and alkaloids. Recent examples of compounds belonging to this structural class are the purpurealidins $\mathrm{A}-\mathrm{D}, \mathrm{F}-\mathrm{H}$ isolated from the sponge Psammaplysilla purpurea, ${ }^{3}$ trisulfide psammalin A, $(E, E)$ bromopsammalin A and bispsammalin A from the association of the sponges Jaspis wondoensis and Poecillastra

*e-mail: rgsberlinck@iqsc.usp.br wondoensis ${ }^{4}$ purpuroceratic acids $\mathrm{A}$ and $\mathrm{B}$ from Pseudoceratina purpurea, ${ }^{5}$ several new and known psammalins active as histone deacetylase and DNA methyltransferase inhibitors, from the sponge Psammaplysilla purpurea, ${ }^{6}$ the moderately cytotoxic purealidin $\mathrm{S}$ and purpuramine $\mathrm{J}$ isolated from the sponge Druinella sp., ${ }^{7}$ and nakirodin A from an unidentified Verongida sponge. ${ }^{8}$

We have recently reported the isolation of two new members of the dibromotyrosine derivatives, caissarines A (1) and B (2), from the sponge Aplysina caissara. Both caissarines were identified by analysis of spectroscopic data. ${ }^{9}$ However, due to the lost of the samples of both $\mathbf{1}$ and 2, we have been unable to measure their specific rotation and to evaluate their biological activities. Therefore, we 
have been interested to re-isolate the compounds in order to complete their characterization and to evaluate their biological activities. Surprisingly, a first recollection of the sponge A. caissara did not provide any dibromotyrosine derivative. ${ }^{9}$ Since the recollected sponge was stored in $\mathrm{EtOH}$ at room temperature for several weeks, we considered that the sponge metabolites could suffer degradation under these conditions. It has been indeed reported that dibromotyrosine metabolites of the sponge A. aerophoba can degrade in the presence of alcohol- $\mathrm{H}_{2} \mathrm{O}$ mixtures, since the enzymatic activity is not completely suppressed under such conditions. ${ }^{10}$ Nevertheless, similar experiments carried out with extracts of the sponges $A$. insularis and A. archeri did not presented similar results, since the dibromotyrosine metabolites of these sponges did not suffer degradation when stored in alcohol. ${ }^{11}$ A second recollection of $A$. caissara, followed by immediate animal freezing at $-20{ }^{\circ} \mathrm{C}$, rapid transportation to laboratory, freeze-drying and extraction, yielded, after several chromatographic separations, no trace of caissarines A (1) and B (2), ${ }^{9}$ but gave fistularin-3 (3), ${ }^{12}$ 11-hydroxyaerothionin (4), ${ }^{13}$ and five unprecedented dibromotyrosine derivatives, named agelocaissarines A1 (5), A2 (6), B1 (7), B2 (8) and caissarine $\mathrm{C}(\mathbf{9})$. Herein we report the isolation and structure determination of the new dibromotyrosine derivatives 5-9 as well as the absolute configuration of the spiroxazolidine moiety of compounds $\mathbf{3}, \mathbf{4}$ and $\mathbf{9}$ isolated from A. caissara. We have also evaluated the antibiotic activity of fistularin3 (3) and 11-hydroxyaerothionin (4) against several pathogenic bacteria.

\section{Experimental}

\section{General experimental procedures}

UV spectra were recorded on a Hitachi U-3210 spectrophotometer. IR spectra (film on Si plate) were recorded on a FT-IR Bomem MB102 infrared spectrometer. Specific rotations were measured on a Perkin Elmer 241 polarimeter in $\mathrm{MeOH}$. NMR spectra were recorded either on a Bruker ARX 9.4 T instrument, operating at $400 \mathrm{MHz}$ for ${ }^{1} \mathrm{H}$ and $100 \mathrm{MHz}$ for ${ }^{13} \mathrm{C}$ channels, respectively, or on a Bruker DRX300 7.05 T, operating at $300 \mathrm{MHz}$ for ${ }^{1} \mathrm{H}$ and $75 \mathrm{MHz}$ for ${ }^{13} \mathrm{C}$, respectively. All NMR spectra were obtained at $25{ }^{\circ} \mathrm{C}$ using TMS as internal reference. Low and high resolution mass spectra were recorded either on a VG-7070 mass spectrometer, using electron impact at $70 \mathrm{eV}$, FAB or CI, or on a Bruker-Hewlett Packard 1100 Esquire-LC system mass spectrometer. Solvents used for extraction and flash chromatography were distilled prior to use. HPLC-grade solvents were utilized without further purification in HPLC separations. TLC analyses were performed with plastic-backed Si gel TLC sheets, eluting with different mixtures of $\mathrm{MeOH}$ in $\mathrm{CH}_{2} \mathrm{Cl}_{2}$. Plates were visualized under UV $\left(\lambda_{\max } 254 \mathrm{~nm}\right)$. HPLC separations were performed either with a Waters quaternary pump 600 , double beam UV detector 2487, and data module 746, or with a Waters autosampler 717, Waters 600 pump, Waters 2996 photodiode array detector monitored by Waters Millenium 32.
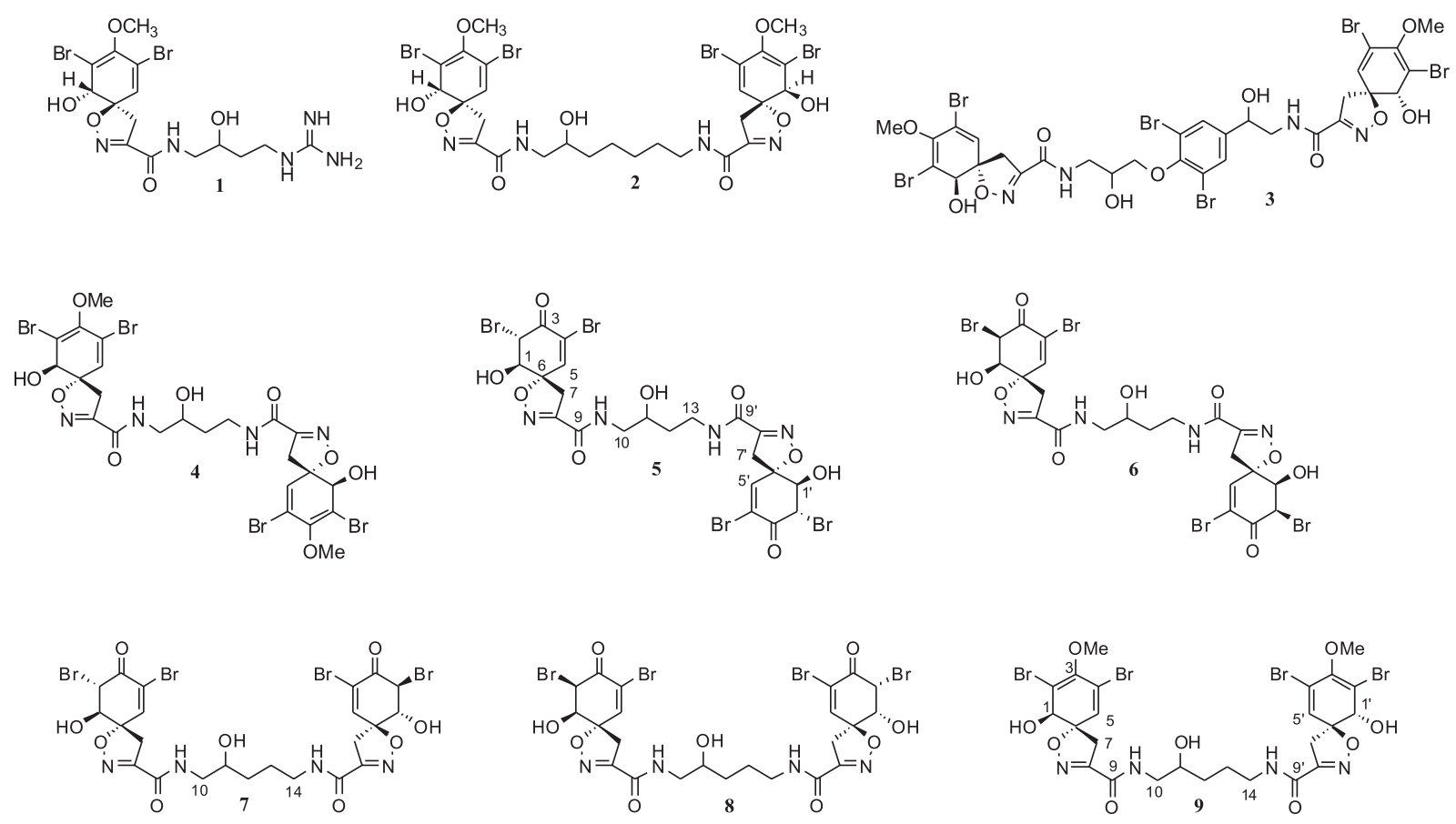
Animal collection and identification. The sponge Aplysina caissara (Pinheiro \& Hajdu, 2001) was collected during the summer of 2002 at the São Sebastião channel and immediately frozen at $-20{ }^{\circ} \mathrm{C}$. A voucher specimen was deposited at the Museu Nacional, Universidade Federal do Rio de Janeiro. ${ }^{9}$

\section{Isolation of compounds 3-9 from Aplysina caissara}

The frozen sponge (1278 g) was freeze dried to give $317 \mathrm{~g}$ of dry material which was sequentially extracted with $\mathrm{MeCN}$, acetone and $\mathrm{MeOH}$. The $\mathrm{MeCN}$ and acetone extracts were separately filtered and evaporated to give brown gums. The $\mathrm{MeOH}$ extract was filtered, concentrated to $400 \mathrm{~mL}$ of an aqueous suspension, which was partitioned with EtOAc $(3 \times 400 \mathrm{~mL})$. The organic layer was evaporated, solubilized in $\mathrm{MeOH}$ and filtered to eliminate inorganic salts, to yield a dark gum. The $\mathrm{MeCN}$, acetone and EtOAC crude extracts have shown to be virtually identical by TLC analysis $\left(\mathrm{CH}_{2} \mathrm{Cl}_{2}-\mathrm{MeOH} 9: 1\right)$, and were pooled to a single crude extract $(9.25 \mathrm{~g})$. This crude extract was subjected to a series of chromatographic separations by flash chromatography on silica gel (gradients of $\mathrm{MeCN}$ in $\mathrm{CH}_{2} \mathrm{Cl}_{2}$ ), by $\mathrm{C}_{18}$ reversed phase column chromatography (gradient of $\mathrm{MeOH}$ in $\mathrm{H}_{2} \mathrm{O}$ ), followed by purifications by HPLC with either a $\mathrm{C}_{18}$ reversed phase column (Waters $\mu$ Bondapak 7.8 x $300 \mathrm{~mm}$, $10 \mathrm{~m}, 100 \AA$ ) or a phenyl reversed phase column (Waters $\mu$ Bondapak $7.8 \times 300 \mathrm{~mm}, 10 \mathrm{~m}, 100 \AA$ A) eluting with $\mathrm{MeCN}-\mathrm{H}_{2} \mathrm{O} 7: 3$ or $1: 1$. The compounds were obtained as amorph solids, caissarine C $(\mathbf{9}, 23.0 \mathrm{mg})$, fistularin-3 (3, $40.0 \mathrm{mg})$, 11-hydroxyaerothionin (4, $127.0 \mathrm{mg})$, agelocaissarines $\mathrm{A} 1$ and $\mathrm{A} 2$ (5 and $\mathbf{6}, 4.0 \mathrm{mg}$ ) and agelocaissarines B1 and B2 (7 and 8, $5.0 \mathrm{mg}$ ).

11-Hydroxyaerothionin (4). ${ }^{13}$ Amorphous solid, $[\alpha]_{\mathrm{D}}{ }^{28}+$ $178^{\circ}$ (c $\left.0.0014, \mathrm{MeOH}\right)$. IR (film on Si plate) $v_{\max } / \mathrm{cm}^{-1}$ : 3374, 2936, 1659, 1602, 1545, 1436, 1314, 1272, 1108, 992, 918, 775, 664. HRESIMS $\mathrm{m} / \mathrm{z} 854.8400$ (Calc. for $\mathrm{C}_{24} \mathrm{H}_{26}{ }^{79} \mathrm{Br}_{3}^{81} \mathrm{BrN}_{4} \mathrm{O}_{9} \mathrm{Na}, 854.8310$ ) corresponding to $[\mathrm{M}+\mathrm{Na}]^{+}$.

Agelocaissarine A1 (5) and agelocaissarine A2 (6). Amorphous solid. IR (film) $v_{\max } / \mathrm{cm}^{-1}: 3369,1701,1660$, 1603, 1544, 1431, 1267, 1108, 1002, 912, 780, 669. HRFABMS $m / z, 804.81762$ (Calc. for $\mathrm{C}_{22} \mathrm{H}_{23}{ }^{79} \mathrm{Br}_{3}{ }^{81} \mathrm{BrN}_{4} \mathrm{O}_{9}$, 804.81780) corresponding to $[\mathrm{M}+\mathrm{H}]^{+} .{ }^{1} \mathrm{H}$ and ${ }^{13} \mathrm{C}$ NMR data: see Tables 1 and 2.

Agelocaissarine B1 (7) and agelocaissarine B2 (8). Amorphous solid. IR (film) $\mathrm{v}_{\max } / \mathrm{cm}^{-1}: 3348,1705,1654$,
1602, 1538, 1441, 1268, 1107, 901, 740, 604. HRESIMS $m / z, 840.8303$ (Calc. for $\mathrm{C}_{23} \mathrm{H}_{24}{ }^{79} \mathrm{Br}_{3}{ }^{81} \mathrm{BrN}_{4} \mathrm{O}_{9} \mathrm{Na}, 840.8154$ ) corresponding to $[\mathrm{M}+\mathrm{Na}]^{+}$. ${ }^{1} \mathrm{H}$ and ${ }^{13} \mathrm{C}$ NMR data: see Tables 1 and 2 .

Caissarine $C$ (9). Amorphous solid, $[\alpha]_{\mathrm{D}}{ }^{28}+175^{\circ}$ (c 0.0021 , $\mathrm{MeOH})$. IR (film) $v_{\max } / \mathrm{cm}^{-1}: 3351,2935,1663,1596,1543$, 1439, 1309, 1270, 1220, 1106, 988, 911, 766, 739, 606. HRESIMS $m / z, 868.8544$ (Calc. for $\mathrm{C}_{25} \mathrm{H}_{28}{ }^{79} \mathrm{Br}_{3}^{81} \mathrm{BrN}_{4} \mathrm{O}_{9} \mathrm{Na}$, $868.8467)$ corresponding to $[\mathrm{M}+\mathrm{Na}]^{+} .{ }^{1} \mathrm{H}$ and ${ }^{13} \mathrm{C} \mathrm{NMR}$ data: see Table 3.

\section{Results and Discussion}

Agelocaissarines A1 (5) and A2 (6) were obtained as an inseparable mixture, which displayed a quasi-molecular cluster $[\mathrm{M}+\mathrm{H}]^{+}$at $\mathrm{m} / \mathrm{z} 803,805,807,809$ and 811 by FABMS, indicating the presence of four bromine atoms in the structures. A HRFABMS measurement at $m / z 805$ (measured: $\mathrm{m} / \mathrm{z}$ 804.81762; calculated: 804.81780) indicated the molecular formula $\mathrm{C}_{22} \mathrm{H}_{23}{ }^{79} \mathrm{Br}_{3}^{81} \mathrm{BrN}_{4} \mathrm{O}_{9}$ for both diastereomers. The ${ }^{13} \mathrm{C}$ NMR spectrum of the diastereomeric mixture displayed thirteen signals of the major stereoisomer agelocaissarine A1 (5) and eight signals of the minor stereoisomer agelocaissarine A2 (6) (Table 1). Five ${ }^{13} \mathrm{C}$ signals were assigned to $\mathrm{sp}^{2}$ carbons: one $\alpha, \beta$-unsaturated ketone carbonyl (C-3 and C-3') at $\delta$ 184.1 and one amide carbonyl (C-9 and C-9') at $\delta 160.1$ to both 5 and $\mathbf{6}$, one imine oxide carbon (C-8 and C-8') at $\delta 154.8$ to $\mathbf{5}$ and at $\delta 155.5$ to $\mathbf{6}$, a vinylic methine (C-5

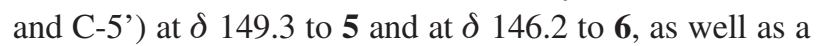
quaternary bromine-substituted $\mathrm{sp}^{2}$ carbon (C-4 and C$\left.4^{\prime}\right)$ at $\delta 122.7$ to $\mathbf{5}(\delta 123.0$ to $\mathbf{6})$. The ${ }^{13} \mathrm{C}$ chemical shifts of the $\alpha, \beta$-unsaturated ketone system were clearly reminiscent to those of agelorins $\mathrm{A}$ and $\mathrm{B}$ isolated from Agelas oroides, ${ }^{14}$ of 11,17-dideoxyagelorins A and B isolated from Suberea aff. praetensa, ${ }^{15}$ of (1'R, 5' $S, 6$ ' $\left.S\right)$ 2-(3',5'-dibromo-1',6'-dihydroxy-4' -oxocyclohex-2'enyl)acetonitrile and its corresponding (1' $\left.R, 5^{\prime} R, 6^{\prime} S\right)$ epimer isolated from Aplysina laevis, ${ }^{16}$ and of an unnamed compound isolated from Aplysina archeri. ${ }^{17}$ Indeed, the remaining carbon resonances assigned to the 4-(4',5'dihydroisoxazolyl)- 2,6-dibromo-5-hydroxycyclohex-2enone moiety of agelocaissarines A1 and A2 were very similar to the corresponding structural moieties of the preceding mentioned natural products. These included the spiro carbon C-6 at $\delta 91.5$ assigned to 5 ( $\delta 90.5$ to $\mathbf{6}$ ), the oximethine carbon $\mathrm{C}-1$ at $\delta 74.5$ for $\mathbf{5}(\delta 74.0$ for $\mathbf{6})$ and the bromine substituted methine $\mathrm{C}-2$ at $\delta 57.2$ for $\mathbf{5}(\delta$ 55.0 for 6). Analysis of the ${ }^{1} \mathrm{H},{ }^{13} \mathrm{C}$ and HMQC NMR spectra of 5 and $\mathbf{6}$ (Table 2) enabled us to assign the ${ }^{1} \mathrm{H}$ 
resonance at $\delta 4.28(\mathrm{dd}, J 2.2$ and $11.4 \mathrm{~Hz}$ ) of compound 5 to H-1 (at $\delta 4.39$ as a broad singlet in 6), at $\delta 4.80$ (dd, $J 1.3$ and $11.5 \mathrm{~Hz}$ ) of 5 to H-2 (at $\delta 5.19$ also as a broad singlet in 6), and the ${ }^{1} \mathrm{H}$ resonance at $\delta 7.51$ (s) to $\mathrm{H}-5$ in compound 5 ( $\delta$ 7.32, s, in compound 6). The $\mathrm{H}-7 \mathrm{a} / \mathrm{H}-7 \mathrm{~b}$ diastereotopic methylene observed at $\delta 3.71$ (1.3 and 18.0 $\mathrm{Hz})$ and $\delta 3.15(\mathrm{dd}, J 2.2$ and $18.0 \mathrm{~Hz})$ in $\mathbf{5}$ and at $\delta 3.76$ (dd, 1.3 and $18 \mathrm{~Hz}$ ) and $\delta 3.29(\mathrm{dd}, J 2.8$ and $18.0 \mathrm{~Hz}$ ) in 6 completed the ${ }^{1} \mathrm{H}$ assignments of the spiroxazolidine moiety of both compounds 5 and $\mathbf{6}$.

Analysis of the ${ }^{1} \mathrm{H}-{ }^{1} \mathrm{H}$ COSY spectrum confirmed these assignments, since $\mathrm{H}-1$ and $\mathrm{H}-2$ were vicinally coupled in 6, while $\mathrm{H}-1$ showed couplings with both $\mathrm{H}-2$ and $\mathrm{H}-7 \mathrm{a} / \mathrm{H}-$ $7 \mathrm{~b}$ (long-range) in compound 5. Additional support for the spirobicyclic moiety assignments of both $\mathbf{5}$ and $\mathbf{6}$ was obtained by analysis of the HMBC spectra, which showed long range couplings between $\mathrm{H}-1$ and C-2, C-6 and C-7, between $\mathrm{H}-2$ and $\mathrm{C}-1, \mathrm{C}-3$ and C-6, between $\mathrm{H}-5$ and C-1, C-3, C-4 and C-7 (weak), as well as between $\mathrm{H}-7 \mathrm{a} / \mathrm{H}-7 \mathrm{~b}$ and C-1, C-5, C-6 and C-8 for compound 5. The same HMBC spectra indicated similar long range couplings between $\mathrm{H}-5$ and C-1, C-3, C-4 and C-7, as well as between $\mathrm{H}-7 \mathrm{a} / \mathrm{H}-7 \mathrm{~b}$ and $\mathrm{C}-1, \mathrm{C}-5$ and $\mathrm{C}-6$ for compound $\mathbf{6}$, but no such couplings were observed for both $\mathrm{H}-1$ and $\mathrm{H}-2$.

Considering the molecular formula established by HRFABMS, agelocaissarines A1 (5) and A2 (6) must present two spirobicyclic moieties joined through a 2hydroxy-1,4-diaminobutane bridge. The presence of the diamine chain was confirmed by analysis of the NMR data. The methylene group at $\delta 3.45(\mathrm{~m})$ and $3.36(\mathrm{~m})$ in the ${ }^{1} \mathrm{H}$ spectrum $\left(\delta_{\mathrm{C}}\right.$ at 45.9$)$ was assigned to $\mathrm{CH}_{2}{ }^{-}$ 10 for both compounds 5 and $\mathbf{6}$, the oxymethine at $\delta$ $3.75(\mathrm{~m})\left(\delta_{\mathrm{C}}\right.$ at 68.8$)$ to $\mathrm{CHOH}-11$, the methylene at $\delta$ $1.55(\mathrm{~m})$ and $1.70(\mathrm{~m})\left(\delta_{\mathrm{C}}\right.$ at 34.6$)$ to $\mathrm{CH}_{2}-12$, and the methylene at $\delta 3.25(\mathrm{~m})$ and $3.31(\mathrm{~m})\left(\delta_{\mathrm{C}}\right.$ at 37.0$)$ to $\mathrm{CH}_{2}-13$. The connection of the 2-hydroxy-1,4diaminobutane chain to the two spiroxazolidine moieties was established through the amide hydrogens, one of them (NH-9a) at $\delta 7.42(\mathrm{bt})$ was vicinally coupled to the methylene $\mathrm{CH}_{2}-10(\delta 3.45$ and 3.36) in the COSY spectrum and showed a long range correlation to the amide carbonyl at $\delta 160.1$. The other amide hydrogen (NH-9a') at $\delta 7.26$ (bt) showed a vicinal coupling to the methylene $\mathrm{CH}_{2}-13$ at $\delta 3.25$ and 3.31 , and also showed a long range coupling to the amide carbonyl at $\delta 160.1$. Since we have not observed a second distinct set of ${ }^{1} \mathrm{H}$ signals of the diamino moiety, except for the methylene $\mathrm{CH}_{2}-10$, we assumed that the structural difference between $\mathbf{5}$ and $\mathbf{6}$ was only the relative stereochemistry of their respective bicyclic spiroxazolidine moieties.
The relative stereochemistry of the major diastereomer agelocaissarine A1 (5) was established by analysis of the ${ }^{1} \mathrm{H}$ NMR spectrum and molecular modeling using both MM2 and MOPAC protocols of the Chem3D software. Considering the presence of three stereogenic centers, it is possible to consider four different relative stereochemistries for the spirobicyclic moieties of $\mathbf{5}$ and $\mathbf{6}$. Since the major diastereomer $\mathbf{5}$ showed H-1 and H-2 vicinally coupled with an $11 \mathrm{~Hz}$ coupling constant, the corresponding dihedral angle $(\phi)$ $\mathrm{H}-1 / \mathrm{C}-1 / \mathrm{C}-2 / \mathrm{H}-2$ in 5 must be either close to $0^{\circ}$ or $180^{\circ}$. Molecular modeling analysis indicated a dihedral angle $\phi$ close to $161^{\circ}$, with a $J_{\text {calc }} 10.9 \mathrm{~Hz}$, for the $1\left(R^{*}\right), 1^{\prime}\left(R^{*}\right)$, $2\left(S^{*}\right), 2^{\prime}\left(S^{*}\right), 6\left(S^{*}\right), 6^{\prime}\left(S^{*}\right)$ stereoisomer, which indicated a $\mathrm{H}-1 / \mathrm{H}-2$ pseudo-trans relationship in compound $\mathbf{5}$. For compound 6, both H-1 and H-2 were observed as broad singlets in the ${ }^{1} \mathrm{H}$ NMR spectrum (see Figure 1), indicating a dihedral angle close to $90^{\circ}$ between these hydrogens. Molecular modeling analysis indicated a dihedral angle close to $80^{\circ}$, with a $J_{\text {calc }} 1.0 \mathrm{~Hz}$, corresponding to the $1\left(R^{*}\right), 1^{\prime}\left(R^{*}\right), 2\left(R^{*}\right), 2^{\prime}\left(R^{*}\right), 6\left(S^{*}\right)$, $6^{\prime}\left(S^{*}\right)$ stereoisomer, in which H-1 and H-2 in 6 must present a pseudo-axial/pseudo-equatorial relationship.

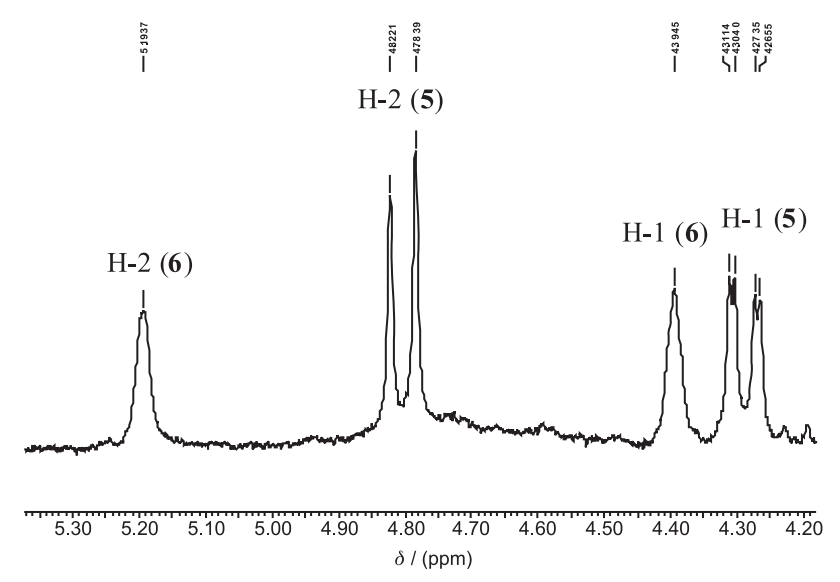

Figure 1. Expansion of the $300 \mathrm{MHz}\left(\mathrm{MeCN}-d_{3}\right){ }^{1} \mathrm{H}$ NMR spectrum of the mixture of agelocaissarines A1 (5) and A2 (6).

Agelocaissarines B1 (7) and B2 (8) were also isolated as an unseparable mixture which displayed a quasi molecular ion cluster at $\mathrm{m} / \mathrm{z} 838,840,842,844$ and 846 . A HRESIMS measurement at $\mathrm{m} / \mathrm{z} 840.8303$ (calc. 840.8154) indicated the formula $\mathrm{C}_{23} \mathrm{H}_{24}{ }^{79} \mathrm{Br}_{3}{ }^{81} \mathrm{BrN}_{4} \mathrm{O}_{9} \mathrm{Na}$ of the corresponding sodium adduct. Therefore, compounds $\mathbf{7}$ and $\mathbf{8}$ were assigned as the higher homologues of compounds $\mathbf{5}$ and $\mathbf{6}$ at the 2-hydroxy diamino chain. This hypothesis was confirmed by analysis of NMR data of $\mathbf{7}$ and $\mathbf{8}$ (Tables 1 and 2), indicating the presence of the additional methylene group $\mathrm{CH}_{2}-13$ at $\delta 1.46$ $(\mathrm{m})$ and $1.55(\mathrm{~m})\left(\delta_{\mathrm{C}} 26.0\right)$, which was vicinally coupled to methylenes $\mathrm{CH}_{2}-12$ at $\delta 1.26(\mathrm{~m})$ and $1.35(\mathrm{~m})\left(\delta_{\mathrm{C}} 32.4\right)$ and 
$\mathrm{CH}_{2}-14$ at $\delta 3.35(\mathrm{~m})$ and $3.24(\mathrm{~m})\left(\delta_{\mathrm{C}} 37.0\right)$ in the COSY spectrum. The remaining NMR data of compounds $\mathbf{7}$ and $\mathbf{8}$ was essentially identical to the corresponding assignments of $\mathbf{5}$ and $\mathbf{6}$, including the relative stereochemistries of the bicyclic spiroxazolidine systems.

The relative stereochemistry of agelocaissarines A1 (5) and A2 (6) as well as of agelocaissarines B1 (7) and B2 (8) are in agreement to the relative stereochemistry established for agelorines A and $\mathrm{B},{ }^{14}$ 11,17-dideoxyagelorins $\mathrm{A}$ and $\mathrm{B},{ }^{15}$ and the monocyclic nitriles isolated from A. laevis. ${ }^{16}$ These compounds have a similar bicyclic spiroxazolidine system, or a monocyclic substituted ring, in which the $\mathrm{CH}_{2}-7$ methylene and the $\mathrm{C}-1$ hydroxyl group have a cis relationship. The hypothesis that the two bicyclic spiroxazolidine moieties within $\mathbf{5}$ and $\mathbf{6}$ or in $\mathbf{7}$ and $\mathbf{8}$ may not have an identical relative stereochemistry was considered, but rulled out since the ${ }^{1} \mathrm{H}$ NMR signals of each single diastereomer had consistent

Table 1. ${ }^{13} \mathrm{C}$ NMR data $\left(75 \mathrm{MHz}, \mathrm{MeCN}-d_{3}\right.$ ) obtained for agelocaissarines A1 (5), A2 (6), B1 (7) and B2 (8)

\begin{tabular}{lcccc}
\hline Position & $\mathbf{5}$ & $\mathbf{6}$ & $\mathbf{7}$ & $\mathbf{8}$ \\
\hline C-1, 1' & 74.5 & 74.0 & 74.5 & 68.5 \\
C-2, 2' & 57.2 & 55.0 & 57.2 & 54.6 \\
C-3, 3' & 184.1 & 184.1 & 184.2 & 183.0 \\
C-4,4' & 122.7 & 123.0 & 122.7 & 123.2 \\
C-5, 5, & 149.3 & 146.2 & 149.4 & 146.3 \\
C-6, 6' & 91.5 & 90.5 & 91.4 & 90.5 \\
C-7, 7, & 38.2 & 41.4 & 38.2 & 41.4 \\
C-8, 8, & 154.8 & 155.5 & 154.8 & 155.5 \\
C-9, 9' & 160.1 & 160.1 & 160.1 & 159.7 \\
C-10 & 45.9 & 45.9 & 45.9 & 45.9 \\
C-11 & 68.8 & 68.8 & 70.3 & 70.3 \\
C-12 & 34.6 & 34.6 & 32.4 & 32.4 \\
C-13 & 37.0 & 37.0 & 26.0 & 26.0 \\
C-14 & & & 37.0 & 37.0 \\
\hline
\end{tabular}

intensities (measured by the integration of ${ }^{1} \mathrm{H}$ signals). In the spectrum of agelocaissarines B1 (7) and B2 (8), the minor diastereomer 8 corresponds to ca. $26 \%$ the amount of 7. In the case of agelocaissarines A1 (5) and A2 (6), the amount of the minor diastereomer $\mathbf{6}$ corresponds to ca. $50 \%$ of compound $\mathbf{5}$. Since in the ${ }^{1} \mathrm{H}$ NMR spectra of compounds 5 and $\mathbf{6}$ and of compounds $\mathbf{7}$ and $\mathbf{8}$ the ${ }^{1} \mathrm{H}$ signals of the bicyclo spiroxazolidine moiety with the $1\left(R^{*}\right), 1^{\prime}\left(R^{*}\right), 2\left(R^{*}\right), 2^{\prime}\left(R^{*}\right), 6\left(S^{*}\right)$, $6^{\prime}\left(S^{*}\right)$ stereochemistry are consistently of lower intensity, it is clear that each compound of the pairs $\mathbf{5}$ and $\mathbf{6}$ as well as $\mathbf{7}$ and $\mathbf{8}$ did not present two bicyclic spiroxazolidine systems with different relative stereochemistry each. This fact is relevant, since it would be possible to consider these compounds as artifacts of isolation generated by acid-catalyzed hydrolysis of the methoxyl group. However, such a hypothesis is questionable due to the following reasons. Firstly, a related metabolite with a 11-keto functionality was isolated from the sponge Aplysina archeri as a single diastereomer. ${ }^{17}$ Secondly, if the bicyclo spiroxazolidine system present in agelocaissarines A1, A2, B1 and B2 and related metabolites isolated from other sponges ${ }^{14-17}$ would be chemically generated in vitro, we would expect to isolate compounds with each of the two bicyclo spiroxazolidine moieties presenting distinct relative stereochemistries. We have been unable to detect such compounds, which are likely to present a very close retention time to the agelocaissarines in the HPLC analysis. The mixture of $\mathbf{5}$ and $\mathbf{6}$ as well as the mixture of $\mathbf{7}$ and $\mathbf{8}$ have proven to be inseparable under several different HPLC separation conditions using reversed phase with $\mathrm{C}_{18}$ or phenyl bonded columns, or using normal phase separation conditions using silica gel or

Table 2. ${ }^{1} \mathrm{H}$ NMR data (300 MHz, MeCN- $d_{3}$ ) obtained for agelocaissarines A1 (5), A2 (6), B1 (7) and B2 (8)

\begin{tabular}{|c|c|c|c|c|}
\hline Position & 5 & 6 & 7 & 8 \\
\hline $\mathrm{CH}-1,1^{\prime}$ & $4.28(\mathrm{dd}, 2.2,11.4)^{*}$ & 4.39 (brs) & $4.14(\mathrm{dd}, 3.0,11.6)$ & 4.24 (brs) \\
\hline $\mathrm{CH}-2,2$ & $4.80(\mathrm{dd}, 1.3,11.5)$ & 5.19 (brs) & $4.65(\mathrm{dd}, 1.0,11.6)$ & 5.05 (brs) \\
\hline \multicolumn{5}{|l|}{$\mathrm{C}-3,3$} \\
\hline \multicolumn{5}{|l|}{ C- $-4,4$} \\
\hline $\mathrm{CH}-5,5$, & $7.51(\mathrm{~s})$ & $7.32(\mathrm{~s})$ & 7.36 (brs) & 7.17 (brs) \\
\hline \multicolumn{5}{|l|}{ C-6, 6} \\
\hline $\mathrm{CH}_{2}-7,7$ & $3.71(\mathrm{dd}, 1.3,18.0)$ and $3.15(\mathrm{dd}, 2.2,18.0)$ & $3.76(\mathrm{dd}, 1.3,18.0)$ and $3.29(2.8,18.0)$ & $3.01(\mathrm{~m})$ and $3.5(\mathrm{~m})$ & $3.72(\mathrm{~m})$ and $3.28(\mathrm{~m})$ \\
\hline \multicolumn{5}{|l|}{$\mathrm{C}-8,8$} \\
\hline \multicolumn{5}{|l|}{ C-9, 9' } \\
\hline $\mathrm{CH}_{2}-10$ & $3.45(\mathrm{~m})$ and $3.36(\mathrm{~m})$ & $3.45(\mathrm{~m})$ and $3.36(\mathrm{~m})$ & $3.20(\mathrm{~m})$ and $3.13(\mathrm{~m})$ & $3.33(\mathrm{~m})$ and $3.49(\mathrm{~m})$ \\
\hline $\mathrm{CH}-11$ & $3.75(\mathrm{~m})$ & $3.75(\mathrm{~m})$ & $3.15(\mathrm{~m})$ & $3.15(\mathrm{~m})$ \\
\hline $\mathrm{CH}_{2}-12$ & $1.70(\mathrm{~m})$ and $1.55(\mathrm{~m})$ & $1.70(\mathrm{~m})$ and $1.55(\mathrm{~m})$ & $1.26(\mathrm{~m})$ and $1.35(\mathrm{~m})$ & $1.26(\mathrm{~m})$ and $1.35(\mathrm{~m})$ \\
\hline $\mathrm{CH}_{2}^{2}-13$ & $3.25(\mathrm{~m})$ and $3.31(\mathrm{~m})$ & $3.25(\mathrm{~m})$ and $3.31(\mathrm{~m})$ & $1.46(\mathrm{~m})$ and $1.55(\mathrm{~m})$ & $1.46(\mathrm{~m})$ and $1.55(\mathrm{~m})$ \\
\hline $\mathrm{CH}_{2}-14$ & & & $3.35(\mathrm{~m})$ and $3.24(\mathrm{~m})$ & $3.35(\mathrm{~m})$ and $3.24(\mathrm{~m})$ \\
\hline NH-9a & 7.42 (brt) & 7.42 (brt) & 7.37 (brm) & 7.37 (brm) \\
\hline NH-9a' & 7.26 (brt) & 7.26 (brt) & 7.20 (brm) & 7.20 (brm) \\
\hline
\end{tabular}

*Multiplicity and coupling constant $(\mathrm{Hz})$ in parentheses. 
phenyl bonded HPLC columns. Therefore, it seems that these compounds are true secondary metabolites, although it has been recently mentioned that prolonged standing of 11 -epi-fistularin-3 at $-20{ }^{\circ} \mathrm{C}$ led to the formation of both agelorins $\mathrm{A}$ and B. ${ }^{18}$

A biogenetic pathway to the formation of the bicyclo spiroxazolidine system present in agelocaissarines A1, A2, $\mathrm{B} 1$ and $\mathrm{B} 2$, as well as in the related metabolites mentioned previously, ${ }^{14-17}$ is proposed in Scheme 1. A possible enzyme-catalyzed methyl extrusion, followed by proton capture concomitantly to the enol ketolyzation gives the bicyclic spiroxazolidine system unique to this class of secondary metabolites, of which only seven related compounds are known up to the present. ${ }^{14-17}$ The enzymatic formation of two different stereoisomers in different proportions suggest that this mechanism has a low stereospecificity, indicating that proton capture may not be enzymatically controlled.

The isolation of 11-hydroxyaerothionin (4) and caissarine C (9) from A. caissara during the present investigation is a support that $\mathbf{4}$ and $\mathbf{9}$ are the biogenetic precursors of each of the diastereomeric pairs, $\mathbf{5}$ and $\mathbf{6}$ and $\mathbf{7}$ and $\mathbf{8}$, respectively. Caissarine C (9) was obtained as an amorphous solid which gave a quasi-molecular sodium adduct $[\mathrm{M}+\mathrm{Na}]^{+}$ion cluster at $\mathrm{m} / \mathrm{z} 866 / 868 / 870 / 872 / 874$. A HRESIMS measurement at $\mathrm{m} / \mathrm{z}, 868.8544$ (calculated: 868.8467) indicated the formula $\mathrm{C}_{25} \mathrm{H}_{28}{ }^{79} \mathrm{Br}_{3}^{81} \mathrm{BrN}_{4} \mathrm{O}_{9} \mathrm{Na}$, corresponding to the 11-hydroxyaerothionin higher homologue (or to the caissarine B lower homologue). This hypothesis was fully supported by analysis of the ${ }^{1} \mathrm{H}$ and ${ }^{13} \mathrm{C}$ NMR (Table 3), ${ }^{1} \mathrm{H}-{ }^{-1} \mathrm{H}$ COSY and HMQC spectra, as
Table 3. ${ }^{1} \mathrm{H}(400 \mathrm{MHz})$ and ${ }^{13} \mathrm{C}(100 \mathrm{MHz})$ NMR data (DMSO- $\left.d_{6}\right)$ obtained for caissarine $\mathrm{C}(\mathbf{9})$

\begin{tabular}{|c|c|c|}
\hline Position & $\delta{ }^{13} \mathrm{C}$ & $\delta{ }^{1} \mathrm{H}$ (multiplicity, $J$ in $\mathrm{Hz}$ ) \\
\hline $\mathrm{C}-1,1^{\prime}$ & 72.4 & \\
\hline C-2, 2' & 119.6 & \\
\hline C-3, 3 ' & 145.9 & \\
\hline C- $4,4^{\prime}$ & 111.9 & \\
\hline C-5, 5 & 130.1 & $6.58(\mathrm{~s})$ \\
\hline$C-6,6$ & $89.0(88.9)^{\mathrm{a}}$ & \\
\hline $\mathrm{C}-7,7$ & 38.5 & $3.20(\mathrm{~d}, 18.2)$ and $3.62(\mathrm{~d}, 18.2)$ \\
\hline $\mathrm{C}-8,8$ & $153.3(153.4)^{\mathrm{b}}$ & \\
\hline C-9, 9' & 157.4 & \\
\hline $\mathrm{C}-10$ & 44.2 & $3.30(\mathrm{~m})$ and $3.00(\mathrm{~m})$ \\
\hline C-11 & $67.2(65.7)^{\mathrm{c}}$ & 3.54 \\
\hline $\mathrm{C}-12$ & 30.6 & $1.40(\mathrm{~m})$ and $1.24(\mathrm{~m})$ \\
\hline $\mathrm{C}-13$ & 24.0 & $1.60(\mathrm{~m})$ and $1.45(\mathrm{~m})$ \\
\hline $\mathrm{C}-14$ & $35.0(32.5)^{\mathrm{c}}$ & $3.15(\mathrm{~m})$ \\
\hline $\mathrm{OCH}_{3}$ & 58.4 & $3.64(\mathrm{~s})$ \\
\hline NH-9 & & $8.51(\mathrm{t}, 5.5)[8.46(\mathrm{t}, 5.8)]^{\mathrm{c}}$ \\
\hline NH-9a & & $8.27(\mathrm{t}, 5.5)[8.32(5,5.8)]^{\mathrm{c}}$ \\
\hline
\end{tabular}

${ }^{a, b}$ Distinct ${ }^{13} \mathrm{C}$ signals for each carbon of the two spiroxazolidine moieties could be observed; 'Distinct signals for two rotamers in solution (see reference 9).

well as by comparison with data reported for 11hydroxyaerothionin ${ }^{13}$ and for caissarine B. ${ }^{9}$

11-Hydroxyaerothionin (4) also was identified by analysis of spectroscopic data, including HRESIMS, ${ }^{1} \mathrm{H}$, ${ }^{13} \mathrm{C},{ }^{1} \mathrm{H}-{ }^{1} \mathrm{H}$ COSY, HMQC and HMBC NMR spectra, as well as by comparison with literature data. ${ }^{19}$ The absolute stereochemistry of $\mathbf{4}$ isolated from A. caissara was established by analysis of ${ }^{1} \mathrm{H}$ NMR and circular dichroism spectra. The ${ }^{1} \mathrm{H}$ spectrum of $\mathbf{4}$ displayed the signals of $\mathrm{H}$ 1 (H-1') and H-6 (H-6') as broad singlets in MeCN- $d_{3}$. Molecular modeling indicated that a $1 R^{*}, 6 R^{*}$ confi-

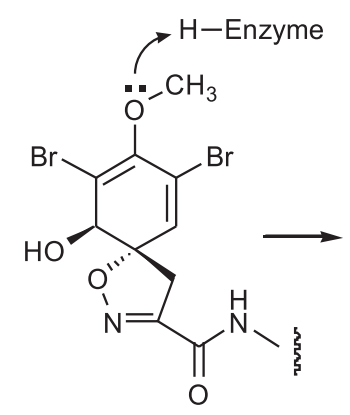

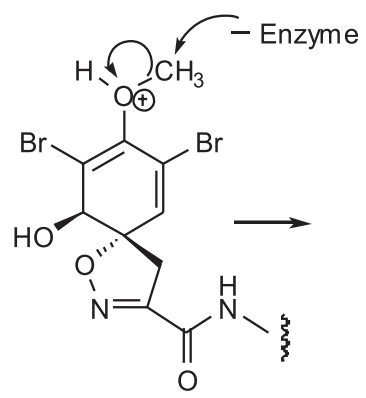

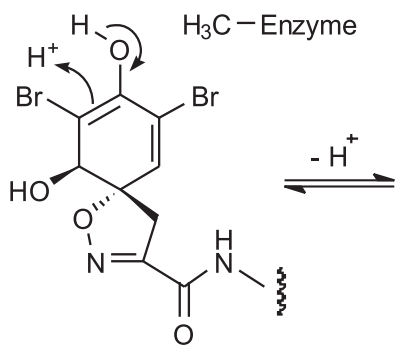<smiles>CNC(=O)C1=NO[C@]2(C=C(Br)C(=O)[C@H](Br)C2O)C1</smiles><smiles>CNC(=O)C1=NO[C@]2(C=C(Br)C(=O)[C@@H](Br)[C@@H]2O)C1</smiles>

Scheme 1. Postulated biogenetic pathway of the agelocaissarines. 
guration would present a $\mathrm{W}$ long range coupling between H-1 (H-1') and H-6 (H-6'), which was not observed in both ${ }^{1} \mathrm{H}$ and COSY spectra. Therefore, the relative configuration should be $1 R^{*}, 6 S^{*}$, which was confirmed by analysis of the CD spectrum of $4\left\{[\theta]_{284}{ }^{\max }+68,000\right.$, $\left.[\theta]_{248}{ }^{\max }+78,000\right\}$, virtually identical to those of 11-epifistularin-3 and aerothionin, both of which have the $1 R$, $1^{\prime} R, 6 S, 6$ ' $S$ absolute configuration. ${ }^{14,19}$ Therefore, the absolute configuration of both spiroxazolidine bicyclic moieties of 4 was assigned as $1 R, 1^{\prime} R, 6 S, 6$ ' $S$. Since the specific rotation of 11-hydroxyaerothionin (4) previously isolated from the sponge Pseudoceratina durissima was $[\alpha]_{D}+189^{\circ}(c=0.15 \text {, solvent not specified })^{13}$ and the specific rotation of $\mathbf{4}$ isolated from A. caissara was $[\alpha]_{D}$ $+178^{\circ}(\mathrm{c}=0.0014, \mathrm{MeOH})$, we can suggest the same absolute configuration for the spiroxazolidine bicyclic moieties of both compounds.

The same $1(R), 1^{\prime}(R), 6(S), 6^{\prime}(S)$ absolute stereochemistry of the spiroxazolidine moieties was assigned for fistularin-3 (3) and caissarine $\mathrm{C}(9)$ isolated from $A$. caissara, based on the analysis of the ${ }^{1} \mathrm{H}$ NMR and CD spectra of $3\left\{[\theta]_{290}{ }^{\max }+67,500,[\theta]_{248}^{\max }+76,000\right\}$ and of $9\left\{[\theta]_{290}{ }^{\max }+90,000,[\theta]_{248}{ }^{\max }+87,000\right\}$. It is worth of mention that the absolute stereochemistry at C-1, C-1', C-6 and C-6' of fistularin-3 (3) isolated from A. caissara is identical to the same compound recently reported from A. cauliformis. ${ }^{18}$ Therefore, if we consider 11-hydroxyaerothionin (4) as the direct biogenetic precursor of agelocaissarines A1 (5) and A2 (6), and caissarine C (9) the precursor of agelocaissarines B1 (7) and B2 (8), the relative stereochemistry assigned for each component of the diastereomeric pairs may be considered as their respective absolute configurations. No attempts have been made to establish the absolute stereochemistry at C-11 of compounds 4-9.

The dibromotyrosine derivatives fistularin-3 (3) and 11-hydroxyaerothionin (4) displayed moderate antibiotic activity against Escherichia coli ATCC 25922 (MIC at $300 \mu \mathrm{g} \mathrm{mL} \mathrm{m}^{-1}$ for $\mathbf{3}$, while $\mathbf{4}$ was inactive), Pseudomonas aeruginosa ATCC 27853 (MIC at 300 $\mu \mathrm{g} \mathrm{mL} \mathrm{m}^{-1}$ for $\mathbf{4}$, while 3 was inactive), oxacillin resistant Staphylococcus aureus strain 8 (MIC at $600 \mu \mathrm{g} \mathrm{mL}^{-1}$ for both 3 and 4), oxacillin resistant $S$. aureus strain 108 (MIC at $50 \mu \mathrm{g} \mathrm{mL}^{-1}$ and $80 \mu \mathrm{g} \mathrm{mL}^{-1}$ for $\mathbf{3}$ and $\mathbf{4}$, respectively), and no activity at all when tested against Pseudomonas aeruginosa and Candida albicans. Compounds 5, 6, 7 and $\mathbf{8}$ were not tested since they were isolated as mixtures.

In conclusion, we described five new dibromotyrosine derivatives from the sponge A. caissara, agelocaissarines A1 (5), A2 (6), B1 (7) and B2 (8), isolated as pairs of diastereomers, and caissarine $\mathrm{C}(\mathbf{9})$. The relative stereochemistry of the bicyclic spiroxazolidine moiety of compounds $\mathbf{5 - 8}$ could be assigned by ${ }^{1} \mathrm{H}$ NMR and molecular modeling analysis. The concurrent isolation of fistularin-3 (3) and 11hydroxyaerothionin (4) enabled us to establish the absolute configuration of the spiroxazolidine moiety in 4 and 9 by ${ }^{1} \mathrm{H}$ NMR and circular dichroism analysis. Compounds $\mathbf{3}$ and $\mathbf{4}$ displayed moderate antibiotic activity against different pathogenic bacteria.

\section{Acknowledgments}

The authors thank to Prof. José Carlos de Freitas and the technical staff of CEBIMar-USP for the many facilities during the sponge collection. The authors are also gratefully indebted to Dr. Norrie Pearce and Prof. Brent R. Copp (University of Auckland, Auckland, New Zealand) and to Dr. David E. Williams and Dr. Prof. Raymond J. Andersen (University of British Columbia, Vancouver, Canada) for their assistance in the MS analyses, as well as to Prof. Gil V. J. Silva and Virginia H. B. Glass (Departamento de Química, Faculdade de Filosofia, Ciências e Letras de Ribeirão Preto, Universidade de São Paulo) in obtaining the NMR spectra. Financial support to RGSB was funded by FAPESP grant 01/03095-5. EH received grants and/or fellowships from CNPq and FAPERJ. T.O.L. thanks CAPES for a MSc scholarship.

\section{Supplementary Information}

Supplementary Information is avaliable free of charge at http://jbcs.sbq.org.br, as PDF file.

\section{References}

1. Faulkner, D. J.; Nat. Prod. Rep. 2002, 19, 1.

2. Blunt, J. W.; Copp, B. R.; Munro, M. H. G.; Northcote, P. T.; Princep, M. R.; Nat. Prod. Rep. 2006, 23, 26.

3. Tilvi, S.; Rodrigues, C.; Naik, C. G.; Parameswaran, P. S.; Wahidhulla, S.; Tetrahedron 2004, 60, 10207.

4. Park, Y.; Liu, Y.; Hong, J.; Lee, C. O.; Cho, H.; Kim, D. K.; Im, K. S.; Jung, J. H.; J. Nat. Prod. 2003, 66, 1495.

5. Kijjoa, A.; Bessa, J.; Wattanadilok, R.; Sawangwong, P.; Nascimento, M. S. J.; Pedro, M.; Silva, A. M. S.; Eaton, G.; Van Soest, R.; Herz, W.; Z. Naturforsch., B: Chem. Sci. 2005, 60, 904.

6. Pina, I. C.; Gautschi, J. T.; Wang, G. Y. S.; Sanders, M. L.; Schmitz, F. J.; France, D.; Cornell-Kennon, S.; Sambucetti, L. C.; Remiszewski, S. W.; Perez, L. B.; Bair, K. W.; Crews, P.; J. Nat. Prod. 2004, 68, 3866.

7. Tabudravu, J. N.; Jaspars, M.; J. Nat. Prod. 2002, 65, 1768. 
8. Tsuda, M.; Endo, T.; Watanabe, K.; Fromont, J.; Kobayashi, J.; J. Nat. Prod. 2002, 65, 1670.

9. Saeki, B. M.; Granato, A. C.; Berlinck, R. G. S.; Magalhaes, A.; Schefer, A. B.; Ferreira, A. G.; Pinheiro, U. S.; Hajdu, E.; J. Nat. Prod. 2002, 65, 796; Saeki, B. M.; Granato, A. C.; Berlinck, R. G. S.; Magalhaes, A.; Schefer, A. B.; Ferreira, A. G.; Pinheiro, U. S.; Hajdu, E.; J. Nat. Prod. 2003, 66, 1039.

10. Ebel, R.; Brenzinger, M.; Kunze, A.; Gross, H. J.; Proksch, P.; J. Chem. Ecol. 1997, 23, 1451.

11. Puyana, M.; Fenical, W.; Pawlik, J. R.; Mar. Ecol. Prog. Ser. 2003, 246, 127.

12. Gopichand, Y.; Schmitz, F. J.; Tetrahedron Lett. 1979, 3921.

13. Kernan, M. R.; Cambie, R. C.; Bergquist, P. R.; J. Nat. Prod. 1990, 53, 615 .

14. König, G. M.; Wright, A. D.; Heterocycles 1993, 36, 1351.

15. Kijjoa, A., Watanadilok, R., Sonchaeng, P., Silva, A. M. S., Eaton, G., Herz, W.; Z. Naturforsch., C: J. Biosci. 2001, 56, 1116.
16. Capon, R. J.; MacLeod, J. K.; Aust. J. Chem. 1987, 40, 341.

17. Ciminiello, P.; Dell'Aversano, C.; Fattorusso, E.; Magno, S.; Carrano, L.; Pansini, M.; Tetrahedron 1996, 52, 9863.

18. Rogers, E. W., Oliveira, M. F., Berlinck, R. G. S., König, G. M., Molinski T. F.; J. Nat. Prod. 2005, 68, 891; Oliveira, M. F., Oliveira, J. H. H. L., Galetti, F. C. S., Souza, A. O., Silva, C. L., Hajdu, E., Peixinho, S., Berlinck, R. G. S.; Planta Med. 2006, 72,437 , in which the absolute configuration of (+)-fistularin3 and 11-deoxyfistularin-3 was correctly drawn but inversely indicated as $1(S), 1^{\prime}(S), 6(R), 6^{\prime}(R)$.

19. McMillan, J. A.; Paul, I. C.; Goo, Y. M.; Rinehart, Jr., K. L.; Krueger, W. C.; Pschigoda, L. M.; Tetrahedron Lett. 1981, 22, 39.

Received: February 28, 2006 Published on the web: August 11, 2006

FAPESP helped in meeting the publication costs of this article. 
Further Dibromotyrosine-Derived Metabolites from the Marine Sponge Aplysina caissara

\author{
Tatiana O. de Lira, ${ }^{a}$ Roberto G. S. Berlinck, ${ }^{*, a}$ Gislene G. F. Nascimento ${ }^{b}$ and Eduardo Hajdu ${ }^{c}$ \\ ${ }^{a}$ Instituto de Química de São Carlos, Universidade de São Paulo, CP 780, 13560-970 São Carlos-SP, Brazil \\ ${ }^{b}$ Faculdade de Ciências da Saúde, Universidade Metodista de Piracicaba, Rodovia do Açúcar, km 156, \\ 13400-901 Piracicaba-SP, Brazil \\ ${ }^{c}$ Museu Nacional, Universidade Federal do Rio de Janeiro, Quinta da Boa Vista, s/n, 20940-040 \\ Rio de Janeiro-RJ, Brazil
}

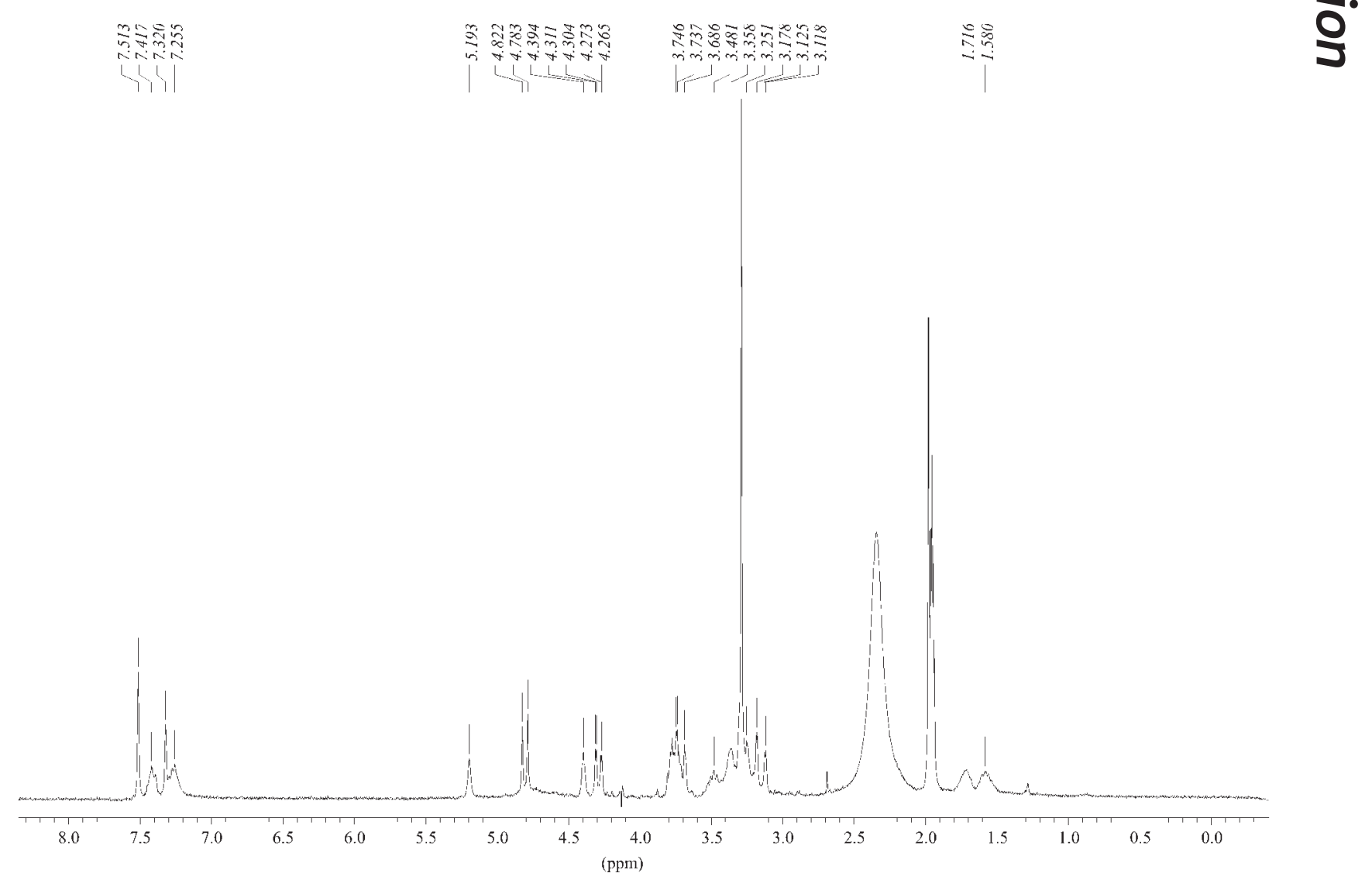

Figure S1. ${ }^{1} \mathrm{H}$ NMR spectrum (300 MHz, MeCN- $d_{3}$ ) of agelocaissarines A1 (5) and A2 (6).

*e-mail: rgsberlinck@iqsc.usp.br 


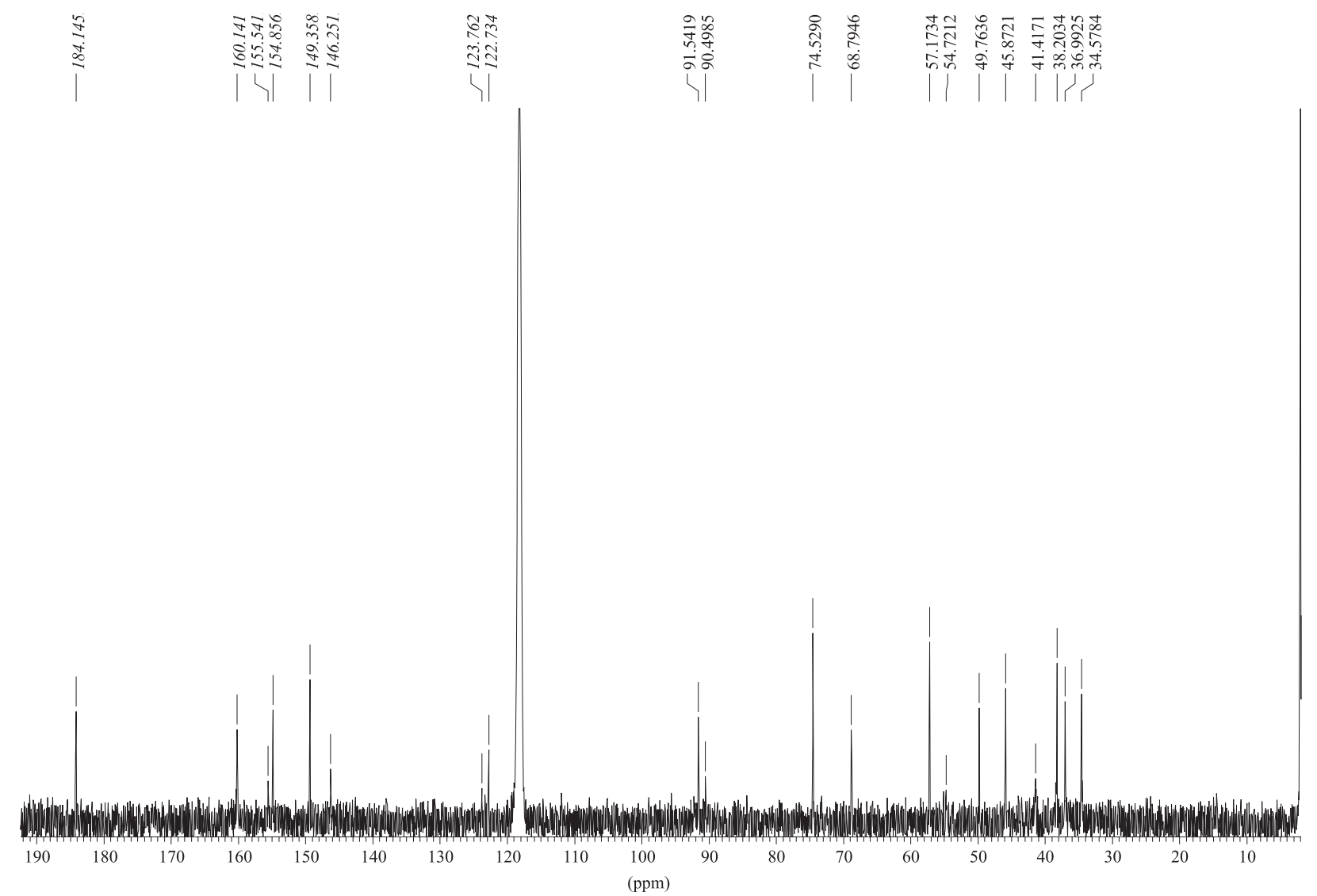

Figure S2. ${ }^{13} \mathrm{C}$ NMR spectrum $\left(75 \mathrm{MHz}, \mathrm{MeCN}-d_{3}\right)$ of agelocaissarines A1 (5) and A2 (6).

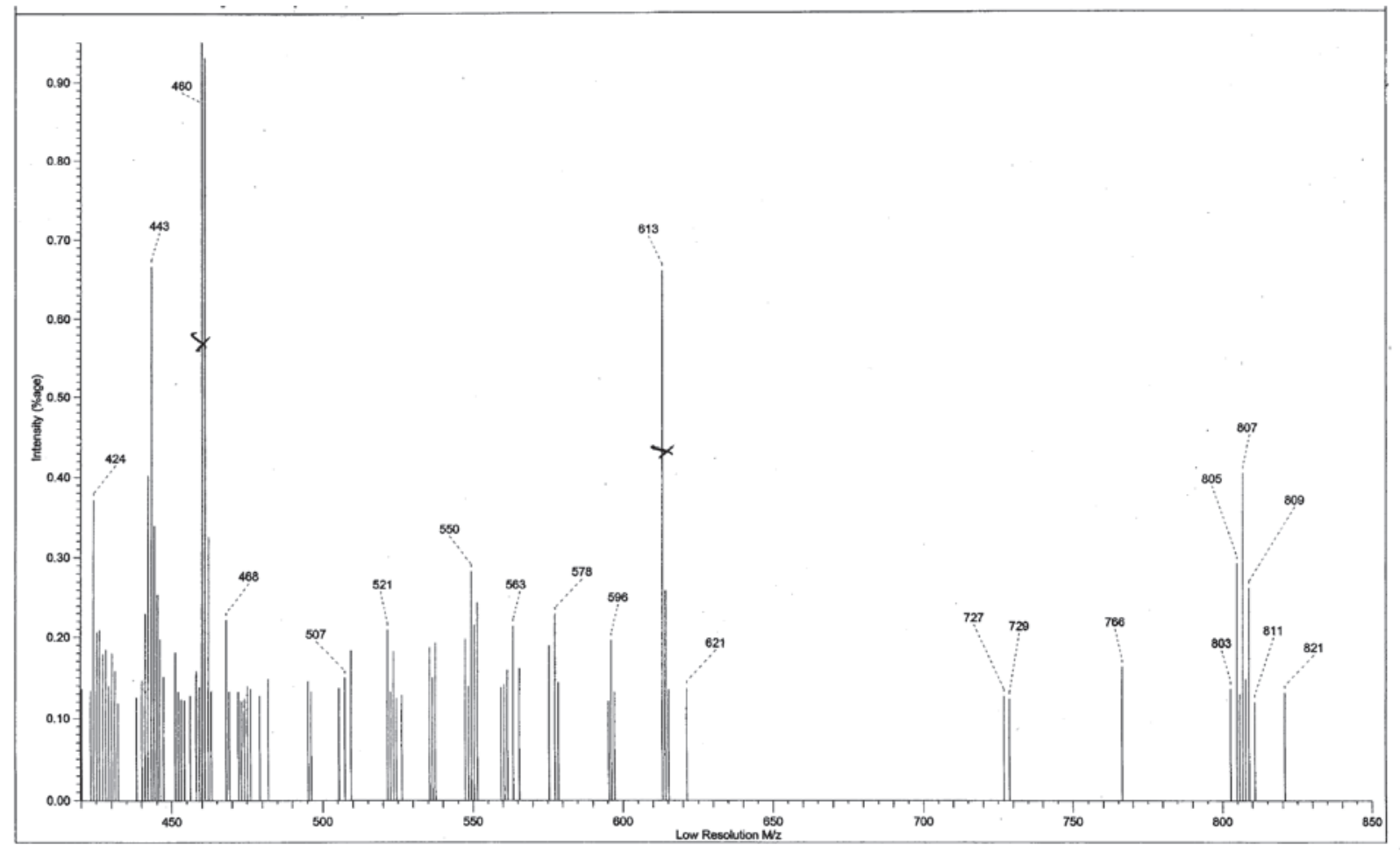

Figure S3. Scanned $\mathrm{FAB}^{+}$mass spectrum of agelocaissarines A1 (5) and A2 (6). 


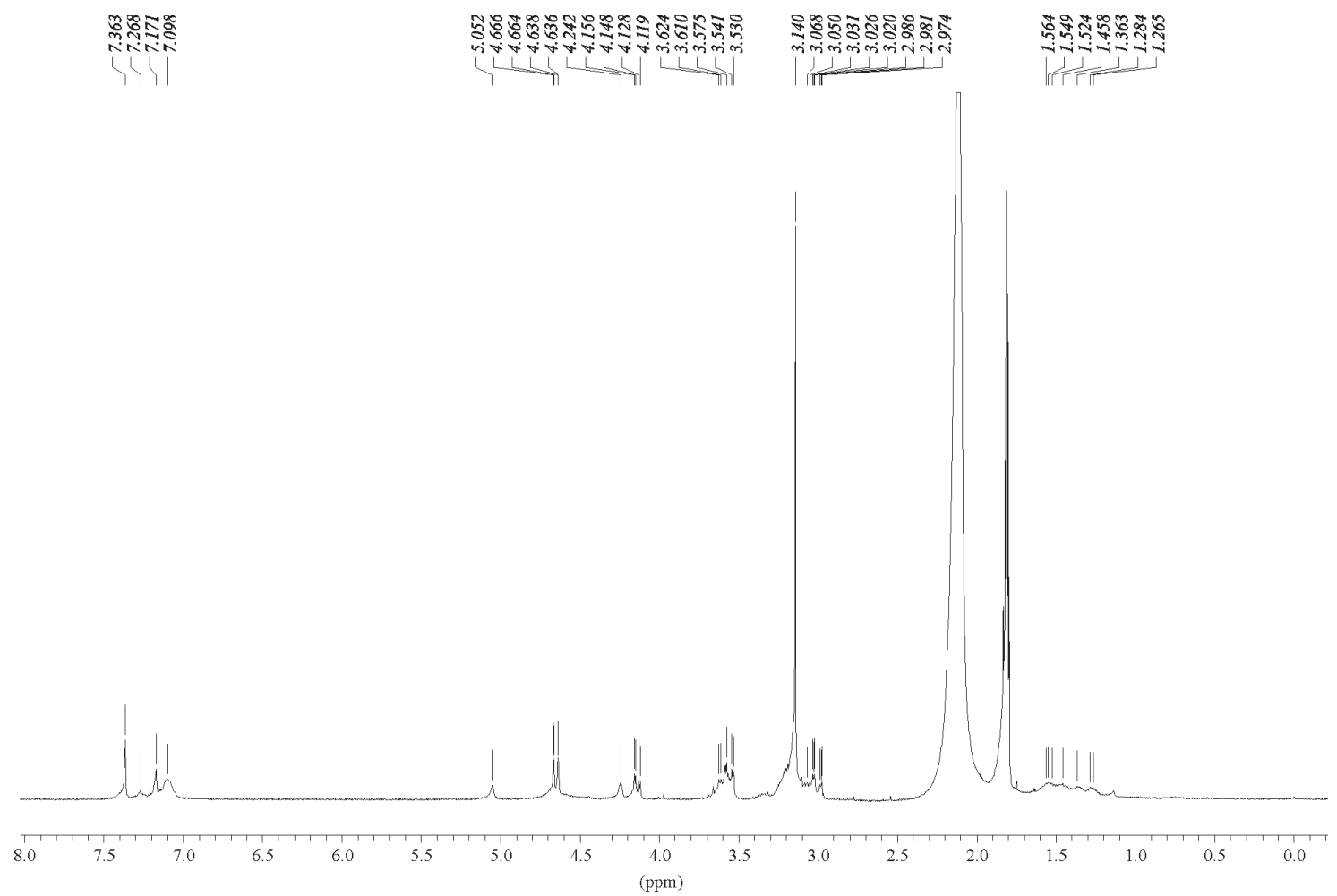

Figure S4. ${ }^{1} \mathrm{H}$ NMR spectrum (MeCN- $d_{3}, 400 \mathrm{MHz}$ ) of agelocaissarines B1 (7) and B2 (8).

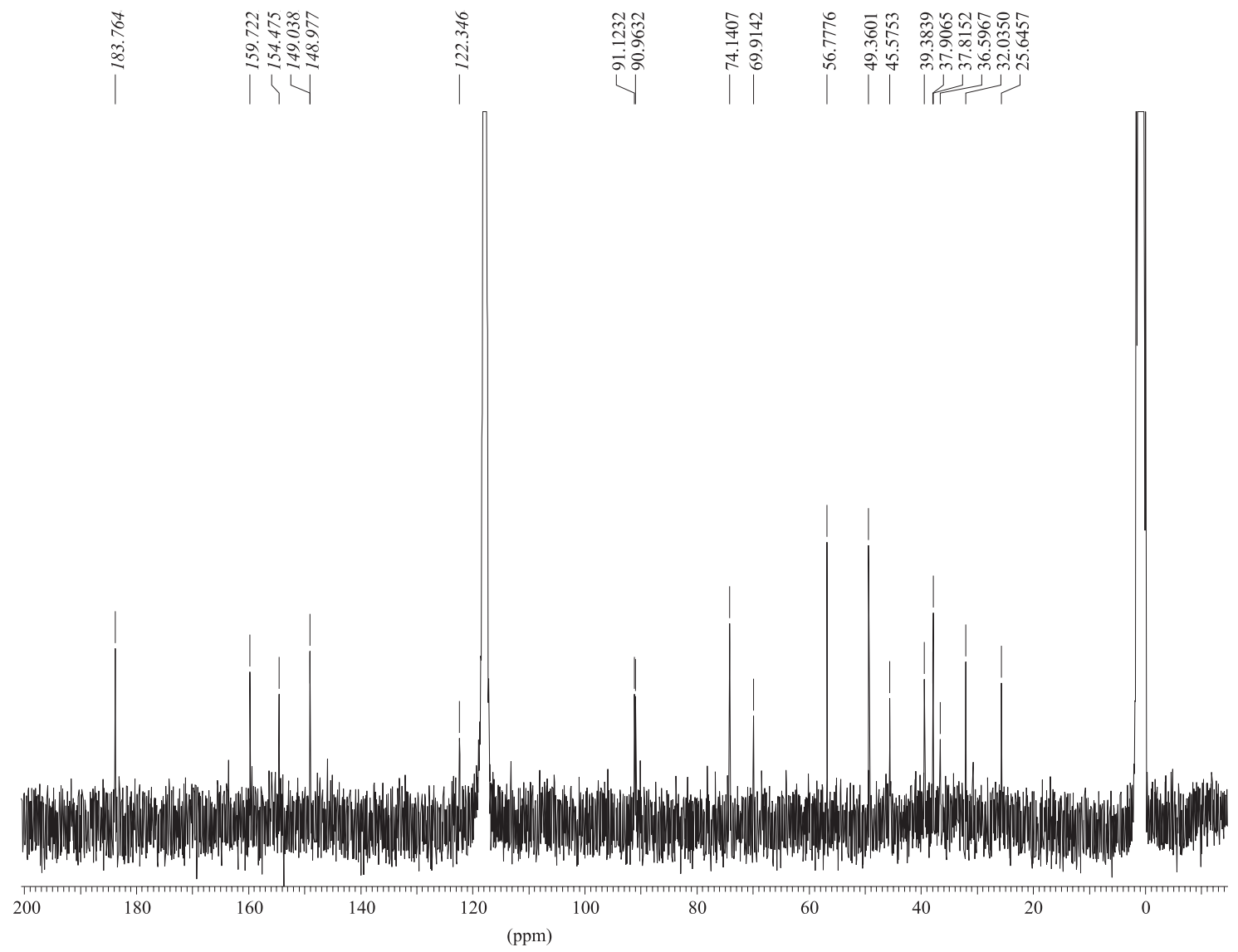

Figure S5. ${ }^{13} \mathrm{C}$ NMR spectrum $\left(75 \mathrm{MHz}, \mathrm{MeCN}-d_{3}\right)$ of agelocaissarines B1 (7) and B2 (8). 


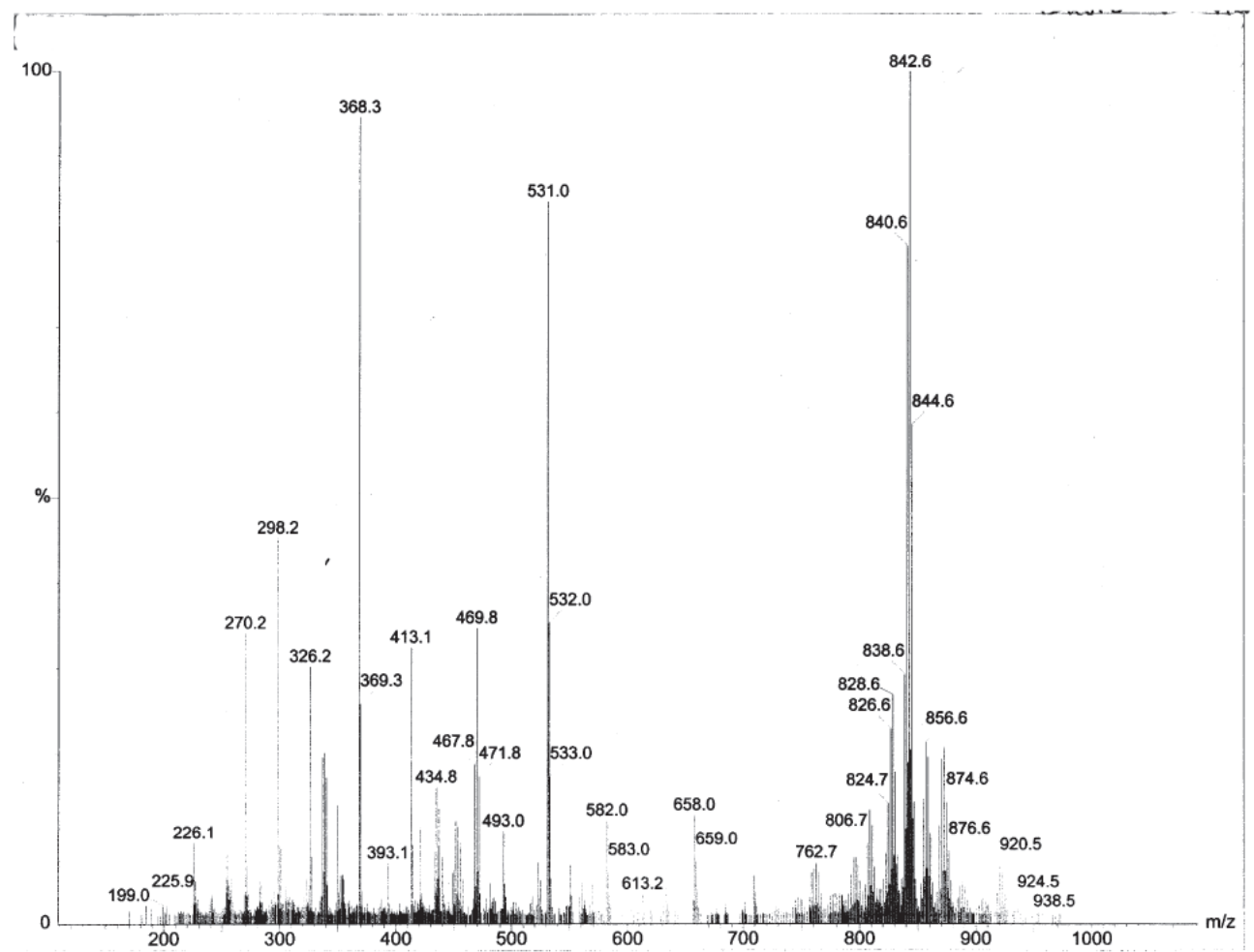

Figure S6. ESI ${ }^{+}$mass spectrum of agelocaissarines B1 (7) and B2 (8).

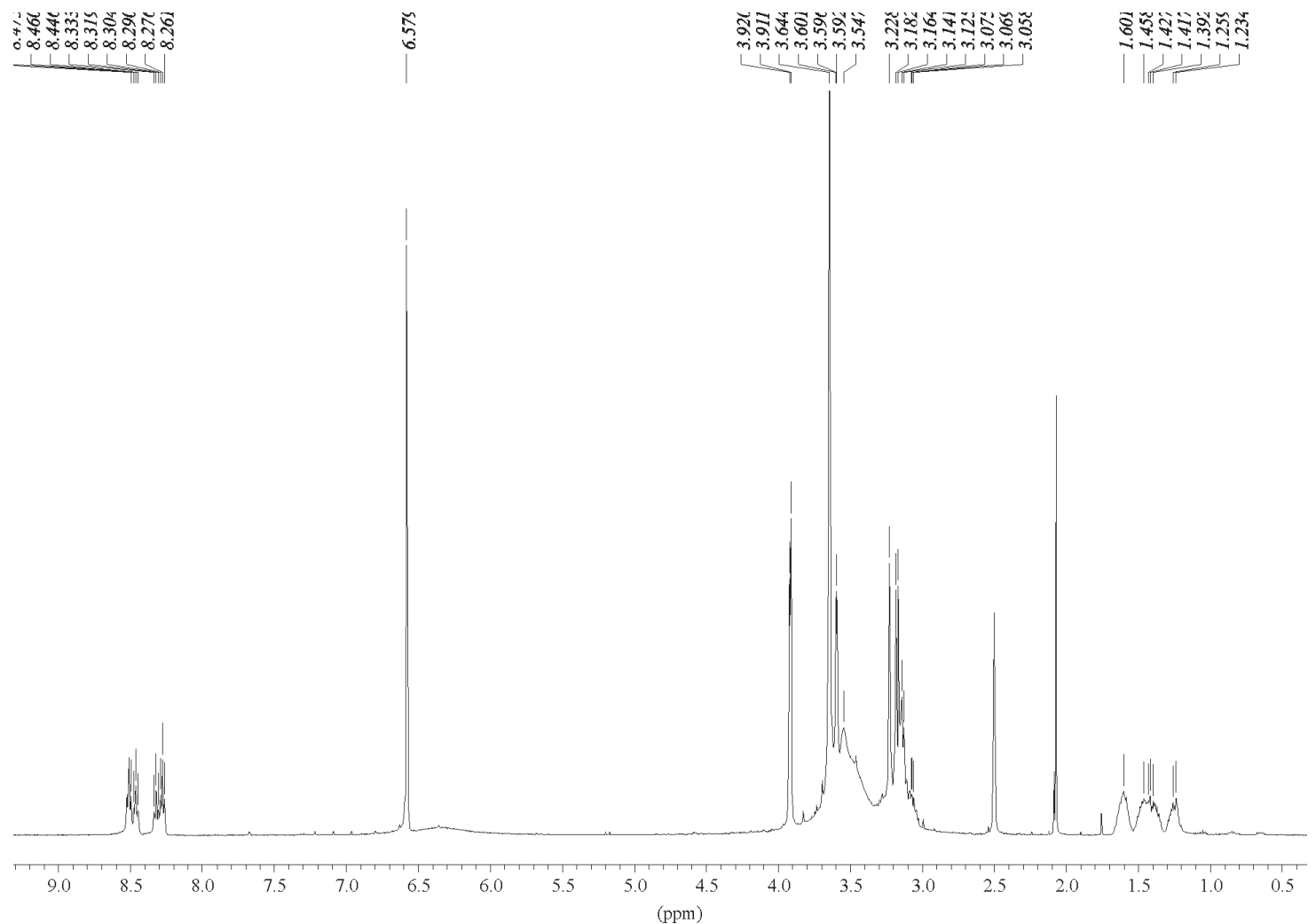

Figure S7. ${ }^{1} \mathrm{H}$ NMR spectrum (DMSO- $d_{6}, 400 \mathrm{MHz}$ ) of caissarine C (9). 


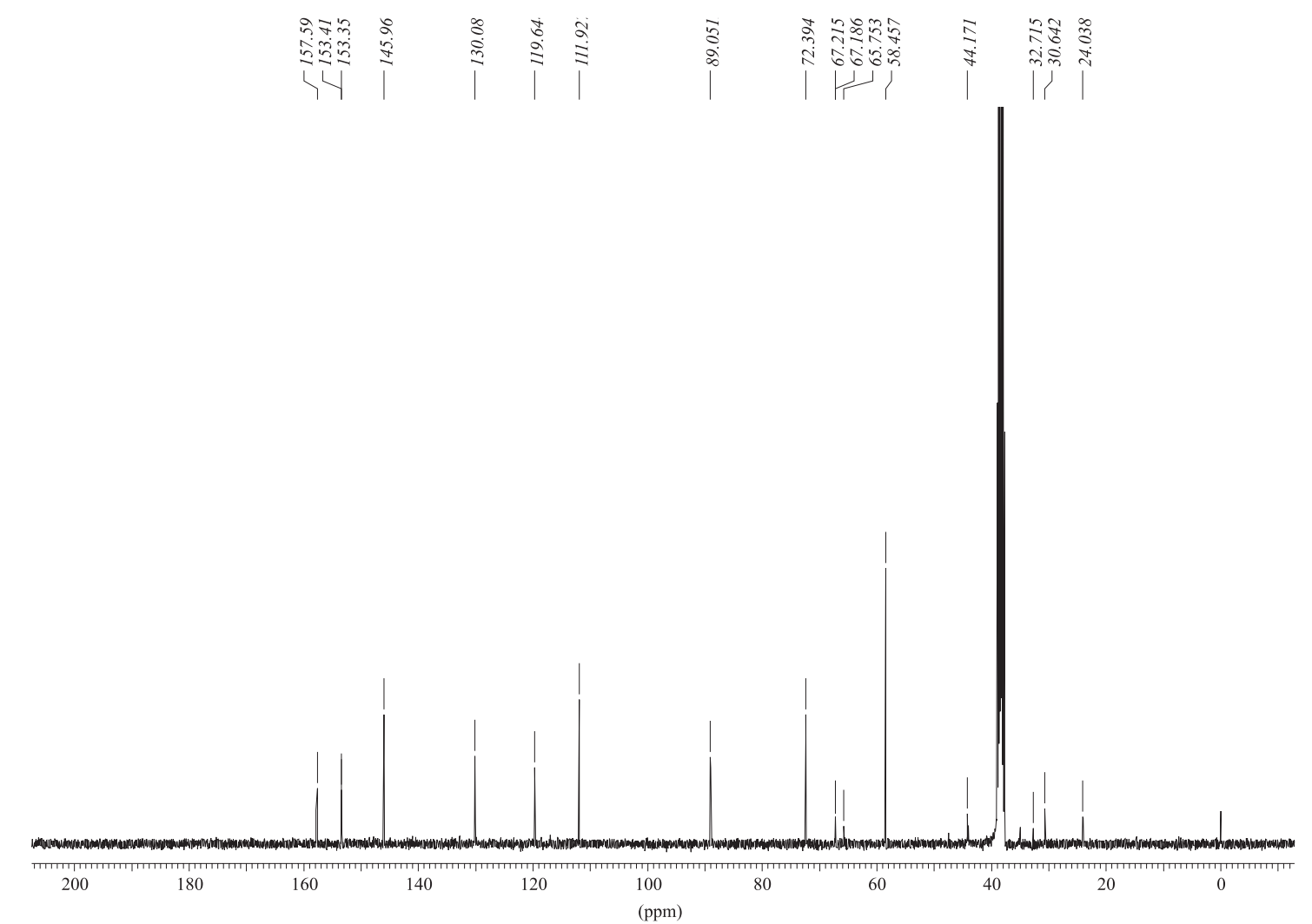

Figure S8. ${ }^{13} \mathrm{C}$ NMR spectrum (100 MHz, DMSO- $d_{6}$ ) of caissarine C (9).

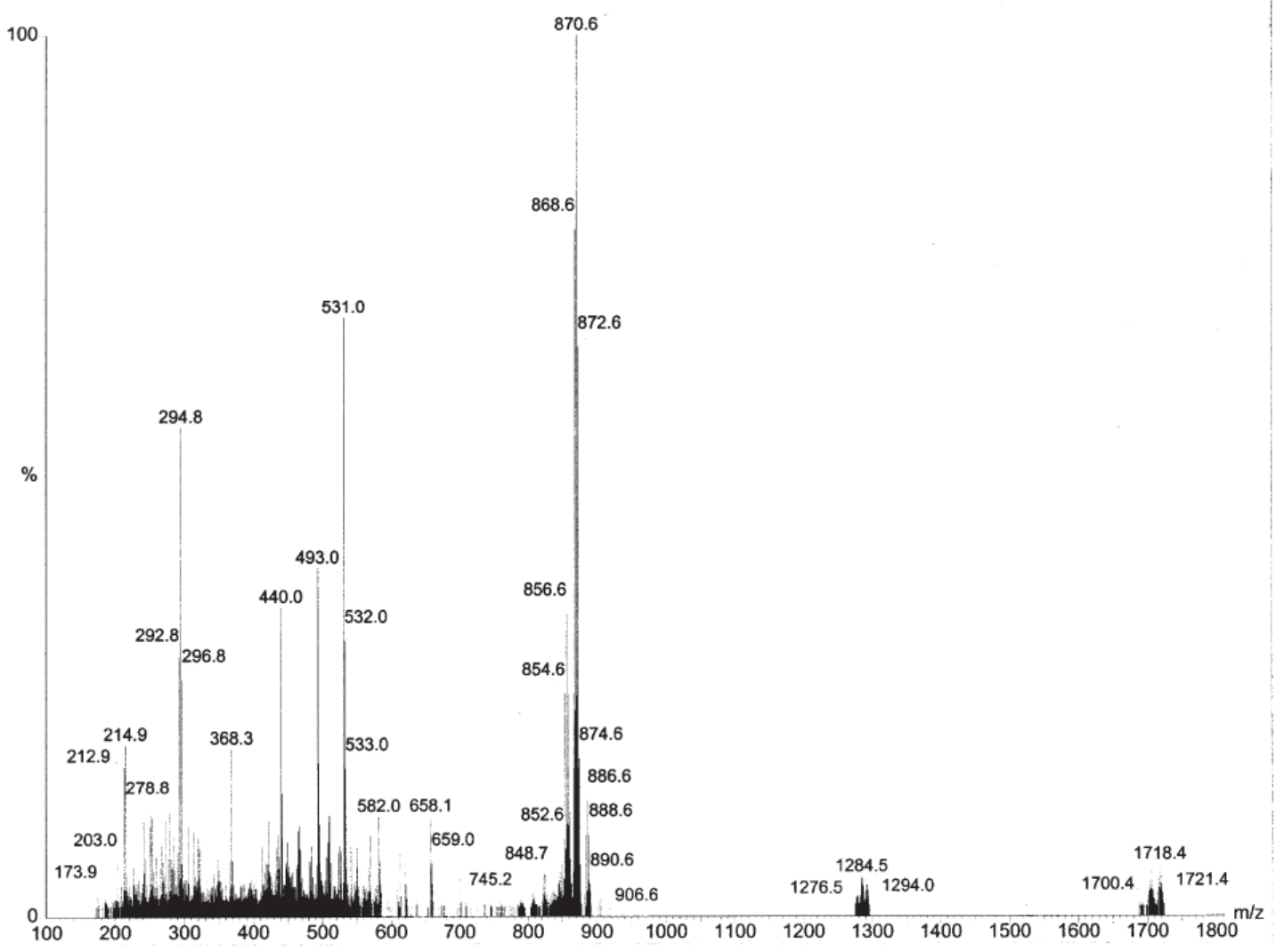

Figure S9. ESI $^{+}$mass spectrum of caissarine C (9). 